\title{
Preserving the Rule of Law in Public Law Cases: Keatings v Advocate General for Scotland and the Lord Advocate
}

\section{A. INTRODUCTION}

In Keatings $v$ Advocate General for Scotland and the Lord Advocate, ${ }^{1}$ the pursuer, a campaigner for Scottish independence, sought two declarators from the Outer House to confirm that the Scottish Parliament had the power to legislate for a Scottish independence referendum without the consent of the UK Government. ${ }^{2}$ Although it concerned a matter of public rather than private law, the case was nevertheless brought as an ordinary action of declarator rather than as a petition for judicial review.

The pursuer made a series of eclectic constitutional arguments in support of his claim that it was within the legislative competence of the Scottish Parliament to legislate for an independence referendum. ${ }^{3}$ Only the first defender offered a response to these substantive claims. ${ }^{4}$ Between them, the first and second defenders argued that the case should be dismissed on a variety of preliminary grounds, namely that the proceedings were academic and hypothetical, that the pursuer lacked title, interest and standing. ${ }^{5}$

Upon hearing the arguments, the Lord Ordinary, Lady Carmichael, dismissed the pursuer's action on the grounds that it was "hypothetical, academic, and premature", and because the pursuer "lack[ed] standing to bring it". ${ }^{6}$ In deciding the case on these preliminary grounds, she refrained from expressing a view on the legislative competence of the Scottish Parliament.

The purpose of this article is to examine key aspects of the Lord Ordinary's reasoning in order to better understand how the decision was reached, as well as the implications it may have for public law in Scotland. It will be shown that the decision, in seeking to clarify the decision of the Inner House in Wightman, ${ }^{7}$ may have set a precedent for a new public law action of declarator. Such an action is distinct from judicial review, but both nevertheless fall within the overarching jurisdiction of the court to preserve the rule of law in public law cases.

\section{B. PRESERVING THE RULE OF LAW IN PUBLIC LAW CASES}

\section{(1) The nature of the jurisdiction}

Questions were raised over whether the action of declarator, because of its public law content, was in reality a petition for judicial review which invoked the supervisory jurisdiction

\footnotetext{
${ }^{1}$ [2021] CSOH 16.

2 Ibid para 1.

${ }^{3}$ Ibid paras 58-76.

${ }^{4}$ Ibid paras 77-89

${ }^{5}$ Ibid paras 14-31 (first defender); paras 32-39 (second defender).

6 Ibid para 139.

${ }^{7}$ Wightman v Secretary of State for Exiting the European Union [2018] CSIH 62 (hereafter "Wightman IH").
} 
This article has been accepted for publication in the Edinburgh Law Review and is forthcoming in issue (2021) 25:2, pp.231-237. For the Edinburgh Law Review, see https://www.euppublishing.com/loi/ELR.

of the court. ${ }^{8}$ The Lord Ordinary however disagreed with the argument that the application in substance invoked the court's supervisory jurisdiction. Reaffirming the scope of judicial review as defined in West $^{9}$ the Lord Ordinary observed the following:

There is here no allegation that the Scottish Parliament has exceeded its powers. No order is sought from the court to reduce any act, or to order performance in relation to an omission. The pursuer seeks advice from the courts as to what the powers of the Scottish Parliament are. While the questions focused in the declarators raise issues of vires, these proceedings are not applications to the supervisory jurisdiction. ${ }^{10}$

Seeking a declarator on a public law matter, therefore, did not make it any less an action of declarator, and the case could proceed on that basis.

Furthermore, even if the application had invoked the court's supervisory jurisdiction as claimed, the Lord Ordinary was nevertheless of the view that this fact alone did not make the application incompetent, noting that she "should have been reluctant to dispose of proceedings raising public law issues simply on the basis that they had been raised using the wrong procedure". ${ }^{11}$ This was because the Lord Ordinary has discretion under the Rules of the Court of Session ("RCS") 58.15 to enable an ordinary action to proceed as a petition for judicial review where the standing requirements of section 27B of the Court of Session Act 1988 are satisfied. ${ }^{12}$ As she noted:

There is no conflict between the necessity to identify whether the jurisdiction invoked is the supervisory jurisdiction or not, and to follow the procedural requirements associated with the jurisdiction in question, and the imperative to avoid situations in which procedural niceties could stand in the way of the enforcement by the courts of the rule of law. ${ }^{13}$

\section{(2) Wightman and declarators}

The pursuer seeking declarators drew immediate parallels with the relatively recent decision of the Inner House in Wightman. The Lord Ordinary accordingly had to decide what relevance the case had to the proceedings before her.

In Wightman, a group of politicians brought a judicial review action seeking a declarator from the court on the revocability of Article 50 of the Treaty on European Union ("TEU"). In order to get such a declarator, a referral to the Court of Justice of the European Union ("CJEU") was first required. The declarator was made by the Inner House following the referral to the CJEU stating that, as a matter of EU Law, the UK could unilaterally revoke its notification of withdrawal under Article 50 of the TEU.

\footnotetext{
${ }^{8}$ Keatings para 39.

${ }^{9}$ West v Secretary of State for Scotland 1992 SC 385.

${ }^{10}$ Keatings para 95.

11 lbid para 97.

12 Ibid paras 99-101.

13 Ibid para 99].
} 
In deciding the case, the Inner House unanimously held that the subject matter of the declarator, the revocation of Article 50, was not an academic question, ${ }^{14}$ and that one of the petitioners, a Member of Parliament ("MP"), had an interest in the matter. ${ }^{15}$ This was attributable to the act that, by virtue of the European Union (Withdrawal) Act 2018, there was an impending vote on the withdrawal agreement, and MPs needed to know what their options were before casting their vote.

The Inner House reached this conclusion having considered the requirements of declarators under Scots law, of which the Lord President (Lord Carloway) provides a brief but informative account. ${ }^{16}$ Anyone, he said, can apply to the Court in order to determine what the law is by virtue of the principle of access to justice, with declarators being the "traditional method" of securing an answer to such a legal question. ${ }^{17}$ The right to a legal ruling is not unlimited, however, and has been qualified by case law over many years. ${ }^{18} \mathrm{~A}$ key limitation identified by all three judges, as per Macnaughton $v$ Mcnaughton's Trs, ${ }^{19}$ is that the court should not be asked to decide hypothetical or academic questions. ${ }^{20}$ The Lord President elaborated on the meaning of such questions as follows:

[T] hose that will have no practical effect. In a case where there are no petitory conclusions, the declarator must have a purpose. There has to be some dispute about the matter sought to be declared. The declarator must be designed to achieve some practical result. $^{21}$

Furthermore, this limitation on declarators overlapped with questions of title and interest, a legal relationship which gives rise to a right that is being denied, ${ }^{22}$ which he distilled into the issue of justiciability: "i.e. the pursuer or petitioner has a right to have the question of law decided". 23

On this point, the Lord President stressed the need to distinguish public law cases from private law ones. Indeed, the main authorities on declarators and their limitations had come from private law cases far removed from the facts before the court. ${ }^{24}$ In AXA General Insurance and others $v$ The Lord Advocate, Lord Reed stated that the essential function of the court was "the

\footnotetext{
${ }^{14}$ Wightman IH para 27 (Lord President); paras 36-37 (Lord Menzies); paras 58-60 (Lord Drummond Young).

${ }^{15}$ Ibid para 27 (Lord President); para 39 (Lord Menzies); paras 58-60 (Lord Drummond Young).

16 Ibid paras 21-25. This account was quoted and relied upon by the Lord Ordinary in Keatings para 121.

17 Ibid para 21.

18 Ibid para 22.

${ }^{19}$ Macnaughton v Macnaughton's Trs 1953 SC 387, 382.

${ }^{20}$ Wightman IH paras 22-25 (Lord President); paras 35-36 (Lord Menzies); paras 55-60 (Lord Drummond Young).

${ }^{21} \mathrm{Ibid}$ para 22.

22 Ibid para 23.

23 Ibid para 22.

24 Ibid para 25 (Lord President); paras 35-36 (Lord Menzies).
} 
This article has been accepted for publication in the Edinburgh Law Review and is forthcoming in issue (2021) 25:2, pp.231-237. For the Edinburgh Law Review, see https://www.euppublishing.com/loi/ELR.

preservation of the rule of law, which extends beyond the protection of individuals' legal rights". ${ }^{25}$ Applying $A X A$, the Lord President therefore noted the following:

The merits, in terms of court time and parties' expense, of a restrictive approach which limits access to the courts may be clear, but they are inconsistent with the modern view on the functions of a court in the public law field set out by Lord Reed in AXA ... Although referring specifically to judicial review, and distinguishing litigation under the heading from actions to enforce private rights, Lord Reed ... emphasised the need for an interests, rather than a rights, based approach in the area of public law. ${ }^{26}$

In so doing, the Lord President appeared to be suggesting that the test of sufficient interest, as outlined in AXA, should apply to declarators. As Wightman involved a petition for judicial review, this test would be required anyway as per section 27B of the Court of Session Act 1988. However, there was some doubt expressed in Wightman over whether the case invoked the supervisory jurisdiction of the court at all.

\section{(3) A new public law action of declarator}

Despite the unanimous decision in Wightman, tension nevertheless exists between the obiter views of the Lord President (with whom Lord Menzies agreed) and Lord Drummond Young on the nature of the proceedings before them.

The Lord President expressed doubt over whether the case fell within the scope of the court's supervisory jurisdiction. ${ }^{27}$ Indeed, the same doubts had been expressed by the Outer House. ${ }^{28}$ The Lord President did not see this as a barrier to relief, however, stating the following:

[T] he court's jurisdiction in public law matters is not confined to the review of decisions or failures to act. It may be that the case ought to have proceeded simply by way of an action of declarator rather than a petition for judicial review. However, no procedural point in that regard is taken. ${ }^{29}$

By contrast, Lord Drummond Young saw the matter as falling within the supervisory jurisdiction of the court. ${ }^{30}$ In his view, the scope of this jurisdiction must be determined by reference to its fundamental purpose, namely "to ensure that all government ... and all actions by public authorities are carried out in accordance with the law", a purpose which is "fundamental to the rule of law". ${ }^{31}$ Therefore, whilst acknowledging that the proceedings

\footnotetext{
${ }^{25}$ AXA General Insurance and others v The Lord Advocate and others [2011] UKSC 46, para 169. Cited in Wightman IH para 24.

${ }^{26}$ Wightman IH para 24.

27 Wightman IH para 26.

${ }^{28}$ Wightman $v$ Secretary of State [2018[ CSOH 61 para 37. See also R B Taylor and A L M Wilson, "Brexit, the revocation of Article 50, and the path not taken: Wightman and Others for Judicial Review against the Secretary of State for Exiting the European Union" (2018) 22 Edinburgh Law Review 417.

${ }^{29}$ Wightman IH para 26.

30 Ibid para 66.

${ }^{31}$ Ibid para 67.
} 
This article has been accepted for publication in the Edinburgh Law Review and is forthcoming in issue (2021) 25:2, pp.231-237. For the Edinburgh Law Review, see https://www.euppublishing.com/loi/ELR.

before the court were an "unusual example of the supervisory jurisdiction", he was nevertheless of the view that it fell "squarely within the fundamental purpose of the supervisory jurisdiction". 32

The difference between the two judges' positions was therefore as follows: whereas the Lord President was of the view that an application seeking clarity on a point of public law could be brought as a standalone action of declarator, Lord Drummond Young felt that it fell within the scope of the supervisory jurisdiction of the court as judicial review.

In Keatings, the Lord Ordinary did not explicitly comment on which view she found to be more persuasive, but instead dismissed the suggestion that there was any contradiction between the two at all. She focused on what the dicta had in common, stating that "[t]he jurisdiction exercised in Wightman is properly characterised as one which is necessary to preserve the rule of law in the sphere of public law". ${ }^{33}$ There is, she said, "no conflict between the views expressed by the Lord President and those expressed by Lord Drummond Young in that respect". ${ }^{34}$

In so doing, it is submitted that the Lord Ordinary has succeeded in potentially clarifying the law post-Wightman by implicitly identifying two distinct public law actions under the overarching jurisdiction of the court to preserve the rule of law: (1) the well-established supervisory jurisdiction of the court (judicial review); and (2) a new standalone public law action of declarator. As such, the Lord Ordinary seems to have given force to the Lord President's obiter comments in Wightman on the availability of an action of declarator in addition to judicial review on public law matters.

Evidence of this can be seen clearly from the conclusions the Lord Ordinary drew from the reasoning in Wightman, which she stated as follows:

(1) It is an aspect of the right of access to justice that a person may apply to the court to determine what the law is in a given situation.

(2) The court will not entertain hypothetical, premature or academic questions.

(3) The circumstances that a public authority may assert that it has no intention to take a particular course will not be determinative of whether a question is hypothetical, premature or academic.

(4) In determining what is hypothetical, premature or academic in the context of public law cases it is essential that the court consider the matter in the light of its function to preserve the rule of law, which extends beyond the protection of individual's rights.

(5) In determining whether an individual has standing in a public law case of this sort, the court should follow the approach desiderated in AXA and Walton, ${ }^{35}$ again with a view to fulfilling its function in preserving the rule of law. ${ }^{36}$

\footnotetext{
32 Ibid para 68.

${ }^{33}$ Keatings para 94.

34 Ibid.

${ }^{35}$ Walton v Scottish Ministers [2012] UKSC 44 (citation added).

${ }^{36}$ Keatings para 124.
} 
This article has been accepted for publication in the Edinburgh Law Review and is forthcoming in issue (2021) 25:2, pp.231-237. For the Edinburgh Law Review, see https://www.euppublishing.com/loi/ELR.

These rules govern the granting of a declarator in public law underpinned by the need to preserve the rule of law. Because Wightman involved a petition for judicial review, and a declarator is recognised as a remedy for judicial review under RCS 58.13(3)(b), the rules could apply to judicial review cases where a declarator is sought.

Crucially, however, the Lord Ordinary's application of the rules to Keatings, a standalone action of declarator, demonstrates that they are not dependent on the supervisory jurisdiction being engaged, and can thus be seen to constitute a new public law action of declarator distinct from judicial review. This is further evidenced by the Lord Ordinary's emphasis on the equal applicability of judicial review's sufficient interest test, where unlawful acts are alleged, "to applications for declarators as to the existing state of the law", ${ }^{37}$ such as in Keatings.

\section{(4) Dismissing the action}

Applying Wightman to the facts in Keatings, the Lord Ordinary concluded that the subject matter of the requested declarators was hypothetical, academic and premature. ${ }^{38}$

The Lord Ordinary rejected the arguments from the defenders that provisions within the Scotland Act 1998, in particular those that enabled Bills which raise questions of competence to be decided by the Supreme Court under sections 33 and 40 , excluded the jurisdiction of the court to make declarators about the state of the law. ${ }^{39}$ Despite this, she was nevertheless of the view that:

[I]t will generally ... be premature and pointless for the courts to adjudicate as to the lawfulness of a proposed act of Parliament at any point before it is passed, because it is open to change by way of amendment at the hands of the Parliament itself until it has been passed. Advice in the abstract, or about a draft, or even a bill as presented, would not necessarily avail Members of the Scottish Parliament who wanted to know whether their vote would result in the passing of legislation that was ultra vires. ${ }^{40}$

Once any legislation was passed, options for legal redress either before Royal Assent under the Scotland 1998 of afterwards via judicial review would be available. ${ }^{41}$

Furthermore, the Lord Ordinary concluded that the pursuer lacked standing to bring the action. In Wightman, only one of the petitioners, the MP concerned, had sufficient interest due to the impending vote on ratification of the withdrawal agreement under the 2018 Act. The pursuer, and any other campaigner or voter, was not in an equivalent position to that of the MP in Wightman, and thus lacked sufficient interest. ${ }^{42}$

\footnotetext{
${ }^{37}$ Keatings para 116.

38 Ibid para 139.

${ }^{39}$ Ibid paras 102-112.

${ }^{40}$ Ibid para 131. See also para 103.

41 Ibid para 130.

42 Ibid paras 133-137.
} 
This article has been accepted for publication in the Edinburgh Law Review and is forthcoming in issue (2021) 25:2, pp.231-237. For the Edinburgh Law Review, see https://www.euppublishing.com/loi/ELR.

\section{CONCLUSION}

Following the Lord Ordinary's reasoning in Keatings, assuming it is not overturned on appeal, it seems likely that an answer to whether or not it is within the legislative competence of the Scottish Parliament to unilaterally legislate for an independence referendum will only be answered if and when a Bill is passed. Despite this, the decision of the Lord Ordinary, by building on the decisions of $A X A$ and Wightman, is nevertheless significant in expanding the jurisdiction of the Court to preserve the rule of law in public law cases to the point where a new and distinct public law action of declarator appears to have emerged alongside judicial review. This new action, by no longer restricting public law litigation to unlawful acts, is likely to have a significant impact on the development of Scottish public law and the role of the courts in the years to come.

Robert Brett Taylor School of Law, University of Aberdeen 